\title{
HUM ANIZING SECONDARY SCHOOL CONTEXTS: LEARNING FROM AOTEAROA NEW ZEALAND AND PERU
}

\author{
LETITIA HOCHSTRASSER FICKEL \\ letitia.fickel@canterbury.ac.nz \\ University of Canterbury \\ MARIA NIETO ANGEL \\ maria.nietoangel@pg.canterbury.ac.nz \\ University of Canterbury \\ SONJA MACFARLANE \\ sonja.macfarlane@canterbury.ac.nz \\ University of Canterbury \\ ANGUS HIKAIRO MACFARLANE \\ angus.macfarlane@ canterbury.ac.nz \\ University of Canterbury
}

\begin{abstract}
In the context of secondary education, changes are taking place which serve as an important source of inspiration for considering how to "promote the best possible realization of humanity as humanity" (Dewey, 1966, p. 95). Utilising concepts of care and restorative practice, high school students and staff in three schools in Latin America and Aotearoa New Zealand are engaging with alternative ways of understanding and enacting a "holistic" and "humanizing" education. Theirs is an educational vision that prioritizes learning that promotes notions of relationships - with one's self and with others - through an increased awareness of mutual connection and interdependence. Drawing from an ongoing case study project with these three secondary schools, this article foregrounds student, teacher and principal voices to highlight how these learning contexts are enacting philosophies of care, restoration and forgiveness that serve a humanising educational aim. The article considers how Indigenous perspectives are able to further expand our vision for a holistic, humanising education.
\end{abstract}

Keywords: ethic of care; pedagogies of care; restorative practice; cultural responsiveness; secondary education; aims and ends of education

\section{Introduction}

Globally, socio-political, economic and environmental challenges demand a repositioning of ethical approaches to education, departing from individualism and 
isolationist discourse towards co-responsibility for a shared destiny of humankind. As Biesta (2006) has argued, our most pressing question in this midst of this challenge is "how can we respond responsibly to, and how can we live peacefully with what and with whom is the other" (p. 15). In the educational context, this means revisioning our aims and ends of education to consider anew how to "promote the best possible realization of humanity as humanity" (Dewey, 1966, p. 95), while ensuring a critical humanist lens (Plummer, 2011) that enables a broad notion of humanity, one not bound by particular Western-centric perspectives (Said, 2004). We need to envision models of education that seek inclusion within diversity so as to draw on different worldviews to nurture qualities such as empathy, responsiveness, care and connectedness, coupled with the development of a disposition toward dialogue to resolve differences.

This article was developed in response to the call from the Educational Ideas and Education Policy Special Interest Group of the New Zealand Association for Research in Education to revisit the question of the aims and ends in education. In taking up this call, we have drawn from a larger multi-site case study research project examining how three schools in Latin America and Aotearoa New Zealand are utilising concepts of care and restorative practice to change their school cultures. Theirs is an educational vision that prioritizes learning that promotes notions of relationships - with one's self and with others - through an increased awareness of mutual connection and interdependence. In this way, they seek alternative ways of understanding and enacting for themselves a "humanizing" education. We therefore focus here on foregrounding student, teacher and principal voices to illuminate how these learning contexts serve an inclusive, humanising educational aim. In our discussion, we highlight the ways that the schools drew on and incorporated the values and perspectives of their local Indigenous community to inform their re-visioning of a humanising education.

\section{Challenges in Secondary Education}

Questions about the aims and ends of education are closely linked to achieving more inclusive forms of human coexistence, especially in contexts where social and political dynamics have insufficiently responded to the ideals of social cohesion amid diversity. For example, Latin America is a culturally diverse society. Martinez-Echazabal (1998) has called it a mestizada, a combination of European, African descendants and Indigenous peoples that is rich in culture and natural resources but prone to discrimination and exclusion. In Latin America, young Indigenous people, young Afro-descendants, and youth who experience disabilities, as well as those belonging to the poorest sections of society and working or living in rural areas, are at greatest risk of exclusion or disengagement in secondary schooling (Vezzali, 2016). Similarly, in Aotearoa New Zealand, the Māori population has both historical and contemporary experience of disadvantage in terms of social and educational opportunities and outcomes (Macfarlane, 2004). 
Māori, the Indigenous peoples of the land, are disproportionally overrepresented in a range of negative educational outcomes, including referrals to special education, placement in low stream classrooms, and being in the lowest $20 \%$ of educational attainment (Ministry of Education, 2006; 2011).

Despite extensive diversity between Indigenous cultures globally, they collectively share a common experience, and common cause (Gomez, 2007), one rooted in history of domination, injustice and prejudice. Regardless of different geographic locations, they reflect universal chronicles and experiences, such as the confiscation of their lands, the demise of their languages, knowledge systems and practices, the loss of autonomy, disproportionate poverty, over-representation in poor health and educational outcomes, incarceration, and marginalisation. Throughout the world's history, Indigenous cultures have continually fought for the recognition of their identities, practices and traditions, including their right to retain their languages and resources (Collard \& Palmer, 1984; Stavenhagen, 2005).

According to Champagne (2007), the unique philosophical, pedagogical and epistemological characteristics that define Indigenous cultures are regularly in conflict with those of the dominant culture, and this has particular resonance in education contexts. The oral transmission of knowledge, values, customs, and beliefs from one generation to the next has been an integral pedagogical aspect that defines Indigenous cultures. This practice has served to retain and maintain a wealth of critical cultural knowledge over time, however the oral/aural phenomenon that defines these traditional epistemologies is regularly dismissed and undermined by many dominant cultures who view Indigenous knowledge and constructs as inaccurate, unscientific, baseless, and inferior to the written word (Janke, 1999). This cultural bias is clearly reflected in schools, and in particular secondary schools where there is often a narrower focus on Western-dominated notions of knowledge and curriculum content.

Too often, the educational hegemony arising in such socio-political contexts results in pervasive inequalities that leave young people vulnerable. In Latin America, every 11 years old child is studying, but by the age of 17 , fifty percent of them have abandoned school (Nieves \& Trucco, 2014). Similarly, Aotearoa New Zealand has one of the greatest proportions of disengaged 14-18 year-old students in the OECD countries (Ministry of Education, 2011). By the age of 16,36\% of students in Aotearoa New Zealand are reported to being "usually or always bored" and "one quarter wants to leave as soon as they can, or already have" (Boven, Harland \& Grace, 2011, p. 3). Most often, disengagement leads to school abandonment. For far too many young people that means facing the adult world insufficiently prepared to meet the social, economic and political challenges associated with contemporary living.

The international persistence of disengagement and abandonment in secondary education (OECD, 2016) serves as an imperative to rethink its purpose, and to question more broadly the purpose of education in this global era. Secondary education reform has remained a concern in many countries over the last decades, 
and has been the focal point for policy agendas. Most of these reforms have been based on theoretical and cultural paradigms that place a premium on individual achievement and equate success in life narrowly on economic accomplishment. Under such paradigms, we have seen the rise of a "culture of performativity" (Biesta, 2010, p. 13) where easily measured outcomes and cognitive abilities are generally considered to be more important than socio-emotional aspects such as relational and affective knowledge and skills. Additionally, the prevailing debate on secondary education addresses curriculum or technology, reflecting the widespread belief that young people's uppermost concern is job placement and earnings after graduation.

Young people's own accounts of their schooling experience, however, indicate their sense of the need to also address aspects of meaning and purpose in life (Tenti, 2012). Moreover, in depth analysis of school life, such as ethnographic studies carried out by Levinson (2012) in Mexico, illustrate the need to understand that young students have existential motivations for school attendance. Such existential motivations refer to "the joy and drive to appropriate school knowledge in order to grow as human beings and solve existential problems" (Levinson, 2012, p. 102). Studies that offer a closer look at school experiences where young people find meaning and connectedness may suggest new insights about the aspects of school environments and pedagogies that provide such "existential" motivations. Moreover, such studies can illuminate how such a shift in the aims and ends of education can offer alternatives practices that serve to mitigate student disengagement that can to often lead to school abandonment.

\section{Conceptual Threads: Pedagogies of Care, Restorative Practice, and Cultural Responsiveness}

Ethics of care and pedagogies of care (Noddings, 1984, 2005), restorative practice (Cavanagh, 2009; Narvaez, 2009; Margrain \& Macfarlane, 2011), and culturally responsive practices (Macfarlane, 2007) provide a framework to explore more inclusive visions of education that could re-engage and reconnect young people. This vision of education is based on the ethics of care and conceives the human being as essentially in a responsive relationship with other human beings and the environment (Noddings, 1984; Freire, 1998a; Said, 2004; Biesta, 2006; Boff \& Toro, 2009). Noddings (1984) argued that caring relationships are ontological to human existence. Pedagogies of care are thus defined by the central element of relationships (Sidorkin, 2000) which engender educational practices where teachers and students build the awareness, understanding and willingness to maintain the essential relational characteristic of humanity. Such views align with a critical humanism perspective (Plummer, 2011) which hold ethics of care and compassion central, and champion those values that "give dignity to the person, reduce human suffering, and enhance human well-being" (p. 198). 
The aim of a pedagogy of care is to nurture young people's abilities to care and live together. Relatedness, responsiveness, meaning and connectedness are the undergirding concepts that sustain the theoretical construct of this paradigm (Boff \& Toro, 2009). Freire (1998a) proposed that the "caring teacher" prefers a holistic education that fosters both academic and socio-emotional knowledge and understanding in students. In fact, socio-emotional knowledge is seen as a critical domain in education as it enables the building, maintaining and repairing of relationships that are central to human life. In the light of ethics of care, it is possible to examine how caring student-teacher relationships facilitate a renewed meaning to secondary school experience based on a humanistic approach.

Both Freire and Noddings theorised pedagogical changes that promote this sort of humanising educational approach. Freire (1996, 1998a, 1998b) argued that more democratic educational contexts, in which students and teachers engage in reciprocal teaching-learning relationships, would contribute to democratization of society as a whole. To fulfil this democratising vision, he argued passionately of the need for teachers to acknowledge the cultural and social contexts of students. This notion of the reciprocal nature of the teaching-learning relationship was further expounded on by Noddings $(2005,2013)$ in her conceptualisation of caring pedagogies. For Noddings (2013), caring pedagogies "nurture the caring ethical ideal" (p. 178), implying a renewed significance for schooling. Genuine caring student-teacher relationships manifest "full receptivity" to the particular situation of each student in context (p. 174).

Noddings (2005) also argued for institutional change, noting that moving towards caring pedagogies demands a change in the organisation of schools themselves. Cavanagh (Cavanagh, 2003; Cavanagh, Macfarlane, Glynn, \& Macfarlane, 2012) suggested the notion of a "culture of care" to indicate the values and practices in schools that assume an ethics of care as an educational philosophy. A "culture of care" exists where schools take ownership for students' holistic wellbeing and prioritise building trusting and respectful relationships (Cavanagh, 2003). A caring school is responsive to student's singularity (Biesta, 2006) while nurturing an ethos of co-responsibility.

In a culture of care, young people are given opportunities to learn to care for themselves, care for others and care for nature. Such a culture must also recognise that such human interactions can create care-less situations, breaches and misunderstandings, which affect the dignity of people (Nieto, Monroy, Diaz, Velandia, Mateus, Sabogal \& Narvaez, 2013). Therefore, forgiveness and reconciliation (Botcharova, 2007; Narvaez, 2009), associated with a restoration of dignity, are needed as key strategies within a culture of care. Reconciliative, or restorative, practices teach adolescents how to restore relationships that have been affected by conflicts, and teachers how to embrace alternative, inclusive approaches instead of punitive solutions (Cavanagh, 2009; Margrain \& Macfarlane, 2011). Margrain \& Macfarlane (2011) have thus asserted that ethics of care must also involve transforming school discipline protocols. This is necessary because the 
traditional view of discipline typically resolves conflicts through punishments and exclusion, whereas the perspective of care ethics seeks to resolve the causes that originated negative behaviour and prioritise the reestablishment of truncated relationships. The key concept derived from such approach is restorative practice.

According to Macfarlane (2007), earlier expressions of the culture-of-care practices - encompassing restorative approaches - are found in many Indigenous cultures. The notions of manaakitanga (care) and whakawhanaungatanga (collective responsibility), which are essential in Māori worldview, have their application in the educational context. According to Macfarlane, the concept of manaakitanga is able to be interpreted in several ways in the domain of teaching:

The first is that teachers need to facilitate a range of strategies that will promote the caring process in the classroom (the metaphor of providing abundance of food). Secondly, classrooms need to be socially and culturally safe environments (the metaphor of providing a peaceful place). Thirdly, sound intercultural communication must prevail in the classroom (the metaphor of speaking nicely). Fourthly, manaakitanga is not optional, it is obligatory and it has reciprocal ramifications, suggesting that teachers who value others will be valued in return. (p. 134)

These notions have served as inspiration for interpreting students' needs and proposing new educational approaches. Macfarlane argues that educators must recognize their cultural positioning in such a way that their pedagogy is truly inclusive towards the diversity of cultures, instead of privileging versions of "care" emanating from Western cultural contexts. According to Glynn, Cavanagh, Macfarlane, and Macfarlane (2011) the resulting culturally responsive approaches facilitate caring environments for students of different cultures to flourish.

In sum, taken together, ethics of care, pedagogies of care, restorative and culturally responsive practices can form the foundation for alternative educational models that engage young people's existential motivations for meaning and connectedness, and contribute to young people's holistic well-being and development. They provide alternative frameworks for secondary education where the prevailing educational model tends to homogenise contexts, standardise achievement goals and favour cognitive learning (Gill \& Thomson, 2012). Such revisioning toward this aim of creating a more holistic and humanising education holds great promise for counteracting the current alienation of young people that too often leads to secondary school abandonment (OECD, 2016).

\section{Methodology}

The broader research study from which this article is drawn, seeks to understand what enables restorative practices and ethics of care to become sustainable practices in three secondary schools across two national contexts, Peru and 
Aotearoa New Zealand. A doctoral scholar from Latin America who has been based in an Indigenous research centre at a university in Aotearoa New Zealand has been working collaboratively with the other three authors of her supervisory team in undertaking the broader research study.

Using a multiple case study approach (Merriam, 1988), the broader research study is guided by an interpretative-constructivist framework (Denzin \& Lincoln, 2011) as it seeks to understand the interactions and meaning making among the members of the three school communities. It is also informed by kaupapa Māori research principles and practices, where Māori philosophy and worldview are used in constructing the research process and in forming one's understanding of the outcomes (Macfarlane, Webber, Cookson-Cox \& McRae, 2014, p. 49). The principles of kaupapa Māori research (Smith, 2000; 2005; 2012) guided data collection and the building of trustworthy relationships with the schools. Kaupapa Māori research is consistent with the qualitative tradition and the constructivist paradigm where research is understood as a reciprocal process and relevance is evaluated by all the parties involved (Pihama, Cram \& Walker, 2002; Royal, 2006; Mahuika, 2008).

The three schools selected for the broader study were invited to participate based on the recommendations of experts in the field of restorative practice. These schools, one in Peru and two in Aotearoa New Zealand, have for the last 5-10 years each been on a journey to shift their school culture toward one of care and reconciliation. The impetus for these schools to take up their journey is as unique as the school, though each was concerned with the issues of low academic achievement and disengagement by their students. The diversity of context, location, ethnicity and gender suggested valuable opportunities to learn from a holistic perspective (Table 1). Each of the schools serve a significant number of students from non-dominate ethnic backgrounds. In Aotearoa New Zealand, this means significant number of Māori, who are the Indigenous peoples of the land. In the school in Peru, the student population is mestizaje which refers to the interracial and intercultural mixture among Indigenous, African and European peoples.

Table 1 Contexts of Case Study Schools (2016)

\begin{tabular}{|l|l|l|l|l|l|l|}
\hline School & Country & City/Region & Urban/rural & Students & Ethnicity & Gender \\
\hline $\mathbf{D}$ & Perú & Arequipa & Urban & 318 & Mestizo & $\begin{array}{l}\text { Co- } \\
\text { educational } \\
\text { primary } \\
\text { Single girls } \\
\text { secondary }\end{array}$ \\
\hline T & New Zealand & South Island & Urban & 600 & $\begin{array}{l}25 \% \text { Māori } \\
75 \% \text { Non- } \\
\text { Māori }\end{array}$ & Single boys \\
\hline $\mathbf{O}$ & New Zealand & North Island & Rural & 397 & $\begin{array}{l}45 \% \text { Māori } \\
55 \% \text { Non- } \\
\text { Māori }\end{array}$ & $\begin{array}{l}\text { Co- } \\
\text { educational }\end{array}$ \\
\hline
\end{tabular}


The development of the case studies involved two phases. The first phase focused on developing an initial relationship of trust and collecting documentary information that would serve as a basis for contextualising the case study. Key documents included the school's formal documentation that illustrated the history

of transformation towards a more inclusive and caring environment. The second phase was a two-week immersive visit that allowed for more in-depth data collection with the members of the school community, principal, teachers, students and parents. This included a range of focus groups with students, parents and teachers, as well as in-depth individual interviews with key teachers and the school principal. Other data came from informal conversations with students, families, staff and participation as an observer (Fetterman, 1998) in school settings, such as the library, sports day, and afterschool activities. The intention was to gather a range of educational experiences through the voices of different members of the school community.

For this article, we engaged in a secondary analysis of this data set focused on identifying the broad themes that illuminate the emerging aims and ends of education that the members of the school communities were striving for through their journey with pedagogies of care and restorative practice. In presenting the findings we highlight the key themes that emerged from all three schools providing illustrative student and teacher voices and vignettes related to these themes.

\section{Toward an Holistic and Humanising Education: Perspectives from Students and Staff in Secondary Schools}

Although each of these schools took a unique path in their journey toward restorative practice and pedagogies of care, listening to the voices of the students, teachers and principals it was clear that they held similar perspectives on the aims and ends of education. Each of the schools were grounded in, and drew inspiration from, their local community values and perspectives, and thus were informed by the local Indigenous culture and worldview. They spoke variously of the need to create a holistic education that enabled "care for the human fundamentals," focused on creating "humanizing" experiences that supported young people in their "journey of becoming," and supported members in "becoming a good person." In this way, they envisioned their educational journey as one which serves a humanistic project of society where inclusion, connectedness, inter-dependence and empathy are the focus, and where positive, respectful relationships are the foundation. Though their experiences were grounded in the particular practices and pedagogies they had co-constructed within their school cultures, they nonetheless shared a common concern with the aim of creating a humanising experience of education.

Human fundamentals. Across the schools, the notion of care was associated with the idea of nurturing head, heart and hands (Sergiovanni, 1994). In Aotearoa New 
Zealand, this was captured at one school as a metaphor of the garden, signifying their shared belief that schools should nurture young people and remove obstacles that can inhibit their ability to flourish. Within this school, caring meant that every individual needed to be included, and to feel included. Yet, the principal noted that this is not always the case, as "sometimes we let the school get in the road of the human," implying that schools do sometimes reproduce exclusionary practices and thus they fail in their job to nurture and to help students flourish. Even so, the principal affirmed the need to hold this aspiration because "life and education are the same" and so education should attend first and foremost the "human fundamentals." For him, this meant to be acknowledged, valued, to be cared for, and to be understood. As he pointed out, these are "really simple requests that any human has of another." The principal argued that because schools are social institutions they must serve a higher mission, including the responsibility to meet the basic needs of the student as a human beings based on a sense of dignity, respect and affection.

Interestingly, at this school the annual reports begin with a number of straightforward statistics of the "number of students alive, healthy and attending." This speaks to their prioritizing the human aspect over strictly academic achievements. Similar to Noddings' (2005) contention that, "Relation, except in very rare cases, precedes any engagement with subject matter" (p. 36), the school principal argued that "unless we deal with the human, we are not going to deal with the academic." Supporting this notion of the need to focus on relationships, a teacher from the school explained that before care and restoration evolved as the school philosophy, young Māori were experiencing 25\% lower achievement, as indicated by outcomes on national qualification exams. The school had previously also been challenged by other conflicts, such as violence, disorder, and high suspensions and expulsions. Clearly, the school had a history of being engaged in schooling that reproduced an unjust social order in which Māori populations were overrepresented in low-quality education. However, over the past seven years after taking up a focus on care and restorative practices, school achievement indicators have not only improved but young Māori have managed to excel in school and results exceed the national average.

Journey of "becoming". Staff at one of the schools in Aotearoa New Zealand talked about how they were focused on helping young people in their human journey of "becoming." Focusing on making a connection with the human being who is the student appeared to be a fundamental ethical principle for the teachers in this school. The principal affirmed this focus saying that as the leader his job "is to keep injecting before staff, every day, stories of humanity."

This attention to issues of "humanity" and "being human" often arose in the teachers' practices and their stories of practice. For example, at one teacher working with a group of students used the analogy of the crocodile and its reptilian behaviour to explain education as the process of "humanisation." $\mathrm{He}$ explained how he understands the role of the teacher is "to make you more human," implying 
the need for humans to intentionally focus on their development of their human qualities such as self-awareness, emotional self-control and skills for collaboration. Consistent with Freire's (1996, p. 48) theorisation of education as the means to "become fully human," the teacher affirmed:

My boys and I talk about crocodiles and I say...If I let you be crocodiles no learning will happen...my job is making you more human.... Once they understand they relax and try and modify the reptilian behaviour.... But, no one has ever really sat down and spoke to them about that.

He emphasised clearly the importance of student-teacher conversations that help young men transition from adolescence to adulthood. The focus here being on selfawareness by understanding and naming the emotions and feelings they were experiencing, and then supporting them to develop the skills to manage them and direct them toward positive ends. He noted though that these sorts of conversations have been too infrequent in secondary schools but are a necessary part of helping young people make sense of how they are and who they are becoming.

Within the school they have worked hard to create a "restorative culture" rather than seeing it as a "programme." A key feature of this cultural shift has been the focus on building and maintaining relationships among the students and between students and staff, as well as developing a sense of interdependence and collaboration among the young men. With this educational aim, they have seen a new level of engagement and a dramatic downturn in their rate of suspensions and exclusions. The students are well aware of this atmosphere of care, inclusion, and support for their journey of "becoming" and recognise this culture is not necessarily typical of educational institutions. Discussing together what environment they believe they will find in University, one student captured the general view by saying:

I think when it comes to University you need to, you have to focus on yourself, but to survive at a little school, I feel like it is not all about yourself. To survive in a small school, you need to have friends and things like that. You can't just focus on yourself.

For these students, there are no false hopes about the continuity of an ethos of care and support for them in higher education. It illuminates these young people's sense of concern about this life transition from their secondary school where intergroup relationships matter, and are seen as central to human experience and well-being, to a new context where the individual seems to be paramount. Their school has supported them thus far toward that humanising aim of education. Yet, in identifying their concern over this impending transition, these young men reaffirm the need to envision educational aims that enable young people to develop this sense of interdependence and valuing of human relationships. 
A Holistic approach. The students and teachers in all three schools were of one mind in their view of the need for a holistic view of education, one that was not just focused on the academic. They felt that the holistic approach taken at the schools, one that focused on them as whole and fully rounded people with intellectual, emotional, spiritual and physical needs and aspirations for the future, supported their human journey of "becoming." Among the students and staff in the school in Peru, this was made explicit in how they talked about their focus on "becoming a good person." In highlighting this educational aim, one student in the school described her experiences, saying:

At present there are few schools that actually teach people how to live, because people do not rely only on their knowledge, mere brain, or getting qualifications. People also must know how to be good people because that is how we can function in the world. This is what I value most of this school, it makes us feel we are part of something in common, sharing our interests plus getting knowledge to be out there.

Like others in the school, she believed that the purpose of education is to become a "good person," a "good human being," and learn to live a good life. She suggested that a good human being is balanced, is not only brain, but is also sensitive, compassionate, connected with himself or herself and with the environment. Her description captures the notion of being whole, or both the cognitive and affective as being important.

The holistic focus of the school, and their vision of helping students become a "good person" has arisen from the staff members concerns that their students be able to be resilient in the face of the ethnic discrimination that is rather pervasive in society. The teachers focus on experiential learning for their students, where care and reconciliation are lived and embodied, as a means of building their sense of self and self-worth, and the valuing of and care for others. For example, a teacher of Quechua (Indigenous) ancestry recalled that in his childhood, he accompanied his mother to sell fruit on the streets, enduring abuse and discrimination. From his experience, he learned that "to live as a human person we need to be treated as human." He has used this experience to guide his own vision of teaching. He described a pedagogical experience with his students where he engaged them in sharing gifts with Quechua women who sell in the streets near the school. His aim was that "students feel the human contact that comes from experience and leaves a mark that will form a guiding principle of their lives."

This resonates with Comins' (2009) argument that education, which is based on an ethic of care, should facilitate situations where experience "generates an empathic emotion that fosters understanding" (p. 204). Clearly, this teacher is committed to communicating the principles of caring relationships though experiences which "leave a mark." Moreover, echoing Freire's (1998a) reasoning of the need for ethical grounding in every educational experience, this teacher supported the idea that educators must assist students to become aware of their 
potential to take part in social change. Similar messages about the need for a holistic approach to the aims of education were observed in the schools in Aotearoa New Zealand. As one teacher affirmed, "You don't want someone who can get $100 \%$ in the test who can't relate to people in the workplace, because they are not going to get hired."

It appears that in all the schools they believe the purpose of education must be to educate "a good person;" someone who can relate empathetically and manifest a "well-rounded" personality. Students in the three schools consistently expressed that they find meaning in an education that teaches them how to live with others and to respond to different situations in life by being grounded in an ethic of care. One student in Aotearoa New Zealand recalled the experience of "being brave and compassionate." He shared that,

Back when I was in Year 9 I was being called fat all the time, so I lash out against the guy. After, my mate came up to me and said: "no you should stop this" and he told me "this it is not good" and he was standing up against me. He was brave and then he was caring towards me. He took me to the office to where I could sort out the problem.

Courage and compassion, according to this student, are complementary and critical to the notion of being a "good person" who cares for others. Clearly, within these schools the students are encountering a holistic approach to education that supports them in their journey of becoming human, and in becoming the sort of "good person" that they envision for themselves.

Noddings (2013) has argued that the aim of education should be to nurture the students' abilities to live together in a caring way with every educational encounter contributing to "preserve and enhance caring" (p. 172). In these three schools, students and staff reflected a similar vision of education to which they aspired. They felt strongly that education must nurture the abilities and attitudes of care which make us more human, such as connectedness, interdependence, knowledge of self, and emotional self-management. In nurturing these abilities and attitudes, these schools were engaged in answering the most human of questions: how to "live peacefully with what and with whom is the other" (Biesta, 2006, p. 15). Such humanising practices and aims served to stem the tide of student disengagement and educational abandonment that has become a persistent challenge in many secondary schools that serve culturally diverse youth. Their perspectives and experiences strengthen our understanding of how education can, as Dewey (1966, p. 95) hoped, "promote the best possible realization of humanity as humanity."

\section{Expanding our Vision of a Humanising Education: Taking Account of Indigenous Perspectives}

Foregrounding student, teacher and principal voices illuminated the ways restorative practices and pedagogies of care are engendering secondary school 
cultures that embrace holistic and humanising educational aims and ends (Cavanagh, Vigil, \& Garcia, 2014; Nieto Angel, Cavanagh, Fickel, Macfarlane, \& Macfarlane, 2015). For these schools, this vision of a humanising education was reflective of a more critical vision of humanism (Plummer, 2011) that focused on the value of the human being and the human experience, which required attention to the whole of their students' being: intellectual, social, affective and spiritual. In crafting this holistic view of education, these schools were deeply connected to their communities and were informed by the local Indigenous cultural worldviews. As previously noted, restorative practices and pedagogies of care are grounded in theoretical and empirical scholarship informed by both Indigenous and Western perspectives. How then do Indigenous cultural perspectives serve to expand our vision for a holistic, humanising education?

Different cultural groups or communities, situated in diverse contexts and places, develop distinct worldviews and cultural practices (Rogoff, 2003). While often such worldviews can and do overlap, Indigenous and Western knowledge systems have been noted to have particular strands that differ one from the other (see Barnhardt \& Kawagley, 2005; Macfarlane, 2004):

- a relational worldview in which connections and interrelations between living beings (human and animal) and the natural world are central to understanding the world and living in it;

- placing an emphasis on the big picture and its meaning, rather than focusing narrowly on the parts that make up the whole;

- a focus on acquiring knowledge through active engagement with, and direct experience of, the natural world; and

- a more holistic view of human development, health, and well-being.

In particular, Indigenous cultures in Aotearoa New Zealand and Latin America reflect this type of holistic human approach to human relations and conceptions of care. Take, for example, the notion of kotahitanga in Māori, which signifies unity, bonding, and reciprocity (Macfarlane, 2007) and the notion of maki purarina in Quechua signifying reciprocity (Kowii, 2015). They each capture a core cultural value regarding the importance of relationships and interdependence to society and human living. The Quechua concept of sumak kawsay further connotes the value placed on the realization (aim) of a dignified life in harmony and balance with the universe and humans (Kowii, 2015), a concept that resonates with the notion of mana tangata for Māori, wherein individual rights and collective harmony is also derived from achieving an inner balance with people and nature (Durie, 1994). Within both the Māori and Andean Indigenous worldviews there is a focus on the values that support the aspiration of "becoming more human" and their significance resides in ensuring balance for the personal and the collective in order to achieve broad and mutual welfare (see Table 2).

The values referred to in Table 2 offer an argument for knowledge systems not necessarily being treated as discrete entities, which too often precludes dialogue 
and learning between them. Rather there are opportunities to pay attention to and incorporate discourses that exist across and between cultures, as the shifting focus on education progresses. In that regard Macfarlane, Macfarlane and Gillon (2015) would declare that when woven together, Western and Indigenous philosophical and theoretical threads together can create a more inclusive, humanizing vision of education and offer an alternative approach for considering the aims and ends of education.

Table 2 Examples of Andean and Māori Indigenous Values

\begin{tabular}{|c|c|c|c|}
\hline \multicolumn{4}{|c|}{ Andean Indigenous Values } \\
\hline $\begin{array}{l}\text { Minka } \\
\text { Makipurarina } \\
\text { Alli kawsay } \\
\text { Sumak kawsay } \\
\text { (Kowii, 2015) }\end{array}$ & $\begin{array}{l}\text { Collective responsibility } \\
\text { Reciprocity } \\
\text { Harmony } \\
\text { Good Life }\end{array}$ & $\begin{array}{l}\text { Ayni } \\
\text { Pakta kawsay } \\
\text { Winak kawsay }\end{array}$ & $\begin{array}{l}\text { Solidarity } \\
\text { Equilibrium } \\
\text { Creativity }\end{array}$ \\
\hline \multicolumn{4}{|c|}{ Māori Indigenous Values } \\
\hline $\begin{array}{l}\text { Whanaungatanga } \\
\text { Manaakitanga } \\
\text { Mana tangata } \\
\text { Orangatanga }\end{array}$ & $\begin{array}{l}\text { Collective responsibility } \\
\text { Reciprocity } \\
\text { Balance } \\
\text { Good life }\end{array}$ & $\begin{array}{l}\text { Kotahitanga } \\
\text { Ōritetanga } \\
\text { Auahatanga }\end{array}$ & $\begin{array}{l}\text { Unity } \\
\text { Equilibrium } \\
\text { Creativity }\end{array}$ \\
\hline
\end{tabular}

\section{Conclusion}

At a time when society pursues education in the midst of humanitarian and ecological crisis, pedagogies of care enable us to recover the centrality of holistic education and claim the possibilities for secondary education that truly contribute to inclusion within diversity. Sharing one facet of an ongoing research project exploring restorative practice and pedagogies of care in three secondary schools located in Peru and Aotearoa New Zealand, this article illuminates how these practices support the emergence of humanizing educational aims for students and staff. Though the schools are situated in different contexts, they have nevertheless found common ground in their focus on creating school cultures marked by inclusion, connectedness, inter-dependence and empathy, and where positive, respectful relationships are the norm. The transformation toward this pedagogical approach is developed through a continuous dynamic of openness to change that allows them to adapt their educational philosophies, based in the ethics of human relations and care and reconciliation, to their unique contextual conditions and emerging student needs. 


\section{ACKNOWLEDGEMENTS}

The authors would like to thanks the students, families, teachers, and school leaders at the three case study schools who so generously shared of their time, experiences, and aspirations in support of the broader research from which this article is drawn. We would also like to thank the reviewers for their thoughtful comments that helped strengthen the final manuscript.

\section{REFERENCES}

Barnhardt, R., \& Kawagley, A. O. (2005). Indigenous knowledge systems and Alask Native ways of knowing. Anthropology and Education Quarterly, 36, 8-23.

Biesta, G. (2006). Beyond learning: democratic education for a human future. Boulder, CO: Paradigm Publishers.

Boff, L., \& Toro, B. (2009). Saber cuidar: El nuevo paradigma ético de la nueva civilización. Retrieved from https://americalatinaquequeremos.files.wordpress.com/ 2014/02/toro-boff-saber-cuidardoc-base.pdf

Botcharova, O. (2007). Justice or forgiveness? In search of a solution. Journal of Conflict Resolution, 8, 623-649.

Boven, R., Harland, C., \& Grace, L. (2011). More ladders, fewer snakes: Two proposals to reduce youth disadvantage. Auckland, New Zealand: The New Zealand Institute.

Cavanagh, T. (2003). Schooling for peace: Caring for our children in school. Experiments in Education, 31, 139-149.

Cavanagh, T. (2009). Creating a new discourse of peace in schools: Restorative justice in education. Journal for Peace and Justice Studies, 18, 62-85. Retrieved from http:// www.pdcnet.org/pdc/bvdb.nsf/purchase?openform \&fp=peacejustice\&id=peacejustice_2 009_0018_0001_0062_0085

Cavanagh, T., Macfarlane, A., Glynn, T., \& Macfarlane, S. (2012). Creating peaceful and effective schools through a culture of care. Discourse: Studies in the Cultural Politics of Education, 33(3), 443-455. doi: 10.1080/01596306.2012.681902

Cavanagh, T., Vigil, P., \& Garcia, E. (2014). A story legitimating the voices of latino/hispanic students and their parents: Creating a restorative justice response to wrongdoing and conflict in schools. Equity \& Excellence in Education, 47, 565-579. doi: 10.1080/10665684.2014.958966

Champagne, D. (2007). Social change and cultural continuity among native nations. Plymouth, England: Altamira Press.

Collard, L., \& Palmer, D. (1984). Looking for the residents of Terra Australis: The importance of Nyungar in early European coastal exploration. Perth, Australia: Murdoch University.

Comins, I. (2009). Filosofia del cuidar, una propuesta coeducativa para la paz. Barcelona, Spain: Icaria.

Denzin, N. K., \& Lincoln, Y. S. (2011). The Sage handbook of qualitative research. Thousand Oaks, CA: Sage.

Fetterman, D. M. (1998). Ethnography: step by step (Vol. 17). Thousand Oaks, CA: Sage.

Freire, P. (1996). Pedagogy of the oppressed. London, England: Penguin Education.

Freire, P. (1998a). Pedagogy of freedom: Ethics, democracy, and civic courage. Lanham, MD: Rowman \& Littlefield Publishers.

Freire, P. (1998b). Teachers as cultural workers: Letters to those who dare teach. Boulder, CO: Westview Press. 
Gill, S., \& Thomson, G. (2012). Rethinking secondary education: A human-centred approach. Oxford, England: Pearson.

Glynn, T., Cavanagh, T., Macfarlane, A., \& Macfarlane, S. (2011). Listening to culture. In V. Margrain \& A. H. Macfarlane (Eds.), Responsive pedagogy: Engaging restoratively with challenging behaviour. Wellington, New Zealand: NZCER Press.

Gomez, N. (2007). Healing hidden wounds. Cultural Survival Quarterly, 31(3), 3-15.

Janke, T. (1999). Our culture, our future: A report on Australian cultural and intellectual property rights. Sydney, Australia: Frankel \& Co.

Kowii, A. (2015). El Sumak Kawsay. Retrieved from http://www.lamacchinasognante. com/il-sumak-kawsay/

Levinson, B. (2012). Reduciendo las brechas entre cultura juvenil y cultura escolar docente en America Latina: El desafio institutional par crear una secundaria con sentido. In F. E. Tenti (Ed.), La escolarizacion de los adolescentes: Desafios culturales, pedagogicos y de politica educativa (pp. 79-113). Buenos Aires, Argentina: IIPE UNESCO.

Macfarlane, A. H. (2004). Kia hiwa ra: listen to culture: Māori students' plea to educators. Wellington, New Zealand: NZCER Press.

Macfarlane, A. (2007). Discipline, democracy and diversity: Working with students with behaviour difficulties. Wellington, New Zealand: NZCER Press.

Macfarlane, A., Webber, M., Cookson-Cox, C., \& McRae, H. (2014). Ka Awatea: An iwi case study of Māori students' success. Christchurch, New Zealand: University of Canterbury.

Margrain, V., \& Macfarlane, A. (2011). Responsive pedagogy: Engaging restoratively with challenging behaviour. Wellington, New Zealand: NZCER Press.

Martinez-Echazabal, L. (1998). Mestizaje and the discourse of national/cultural identity in Latin America, 1845-1959. Latin American Perspectives, 25, 21-42.

Merriam, S. B. (1988). Case study research in education: A qualitative approach. San Francisco, CA: Jossey-Bass.

Narvaez, L. (2009). Cultura politica de perdon y reconciliacion Bogota, Colombia: Fundacion para la Reconciliacion.

Nieto Angel, M., Cavanagh, T., Fickel, L. H., Macfarlane, S., \& Macfarlane, A. H. (2015). Una perspectiva humanista para la educacion del futuro: Revelaciones Internacionales. International Multilingual Journal of Contemporary Research, 3, 42-51. doi: 10.15640/imjcr.v3n1a5

Nieto, C., Monroy, P., Diaz, J., Velandia, F., Mateus, L., Sabogal, A., \& Narvaez, L. (2013). Avance de la evaluacion de resultados del pilotaje internacional de la pedagogia del cuidado y de la reconciliacion. Bogota, Colombia: Fundacion para la Reconciliacion.

Nieves, R. M., \& Trucco, D. (2014). Adolescentes: Derecho a la educacion y al bienestar futuro. Santiago de Chile: CEPAL.

Noddings, N. (1984). Caring, a feminine approach to ethics \& moral education. Berkeley, CA: University of California Press.

Noddings, N. (2005). The challenge to care in schools. New York, NY: Teachers College Press.

Noddings, N. (2013). Caring: a relational approach to ethics \& moral education. Berkeley, CA: University of California Press.

OCDE. (2016). Panorama de la sociedad 2016, indicadores sociales de la OCDE Retrieved from http://www.oecd-ilibrary.org/sites/9f5b7713-es/index.html;jsessionid= 
sp20nkggr9sf.x-oecd-live-03?itemId=/content/summary/9f5b7713-es\&mimeType=text/ html\&_csp_=2355d6f4a4df967836a3077a3ee24b0a

Plummer, K. (2011). Critical humanism and queer theory: Living with the tensions. In N. Denzin and Y. Lincoln (Eds.), The Sage handbook of Qualitative Research, $4^{\text {th }}$ edn. (pp. 195-211). Thousand Oaks, CA: SAGE Publications.

Said, E. W. (2004). Humanism and democratic criticism. New York, NY: Columbia University Press.

Sergiovanni, T. J. (1994). Building community in schools (Vol. 1). San Francisco, CA: Jossey-Bass.

Sidorkin, A. (2000). Toward a Pedagogy of Relation. Faculty publications, 17. Retrieved from http://digitalcommons.ric.edu/facultypublications/17

Smith, L. T. (2000). Māori Research Development: Kaupapa Māori principles and practices - A literature review. Auckland, New Zealand: University of Auckland.

Smith, L. T. (2005). On tricky ground: Researching the Native in the age of uncertainty. In N. K. Denzin \& Y. S. Lincoln (Eds.), The Sage handbook of qualitative research $\left(3^{\text {rd }}\right.$ ed.), pp. 85-107. Thousand Oaks, CA: Sage Publications.

Smith, L. T. (2012). Decolonizing methodologies: Research and indigenous peoples. New York, NY: Zed Books.

Stavenhagen, R. (2005). Indigenous peoples: An essay on land, territory, autonomy and self-determination. Available online at Land Research Action Network (LRAN) website: http://landaction.org

Tenti, F. E. (2012). La Escolarizacion de los adolescentes: Desafios culturales, pedagogicos y de politica educativa. Buenos Aires, Argentina: UNESCO, IIPE.

Vezzali, F. (2016). Adolescentes y jovenes por fuera de la escuela: demandas para una enseñanza secundaria garante de derechos en America Latina y el Caribe. Retrieved from http://www.redetis.iipe.unesco.org/publicaciones/adolescentes-y-jovenes-fuera-dela-escuela/-.WOqhdk27q71

Letitia Hochstrasser Fickel is Professor of Teacher Education and Head of School of Teacher Education at the University of Canterbury, New Zealand. Her research focuses on high-quality initial teacher education and teacher professional learning and development that supports culturally and linguistically responsive practice and enhanced student learning.

Maria Nieto Angel is a PhD candidate in the College of Education, Health and Human Development at the University of Canterbury, New Zealand. Her research interests focus on Indigenous knowledge and learning, holistic approaches to education, including cultures of care. She is currently examining how schools promote and sustain caring environments.

Sonja Macfarlane is Associate Professor in the College of Education, Health and Human Development at the University of Canterbury, New Zealand, working in Māori health and wellbeing, psychology, counselling and special education. Her research focuses on culturally responsive evidence based professional practice in order to enhance the social, cultural and educational outcomes that are achieved by Māori learners.

Angus Hikairo Macfarlane is Professor of Māori Research at the University of Canterbury, New Zealand. He has a prolific publication record and has also received many awards for his extensive academic achievements and contributions to Māori education. His research explores cultural concepts and strategies that influence professional practice. 